\title{
Dampak Implementasi Full Day School Dalam Pelaksanaan Pembelajaran Di Sekolah Dasar
}

\author{
Nitya Ruth Oktaviani ${ }^{1}$ \\ ${ }^{1}$ SDN 149/X Tanjab Timur, Jambi, Indonesia
}

\begin{tabular}{l} 
Info Artikel \\
\hline Riwayat Artikel: \\
Dikirim Jan 6, 2020 \\
Revisi Jan 16, 2020 \\
Diterima Jan 28, 2020 \\
\hline
\end{tabular}

\section{Kata Kunci:}

Dampak

Full Day School

Pembelajaran

Sekolah Dasar

\author{
ABSTRAK \\ Tujuan Penelitian: Penelitian ini bertujuan untuk mendeskripsikan dampak \\ yang ditimbulkan dari implementasi full day school dalam pelaksanaan \\ pembelajaran di Sekolah Dasar
}

\begin{abstract}
Metodologi: Penelitian lapangan dengan pendekataan kualitatif. Pengumpulan data dilakukan dengan cara observasi dan wawancara dengan sumber data primer yaitu kepala sekolah, guru, dan peserta didik yang merasakan dampak dari implementasi full day school. Teknik analisis data dalam penelitian ini adalah analisis deskriptif dengan cara mereduksi data, penyajian data dan penarikan kesimpulan. Pengujian keabsahan data dilakukan dengan teknik triangulasi.
\end{abstract}

Temuan Utama: Penelitian ini menghasilkan dua dampak yaitu dampak positif dan dampak negatif. Berdasarkan hasil penelitian dapat disimpulkan bahwa implementasi full day school dalam pelaksanaan pembelajaran menimbulkan beberapa kendala yaitu menimbulkan dampak positif salah satunya seperti meningkatnya prestasi peserta didik dan dari segi negatif yaitu peserta didik mengalami kelelahan karena waktu yang lama.

Copyright $(2020$ Cahaya Ilmu Cendekia Publisher. All rights reserved.

\section{Corresponding Author:}

Nitya Ruth Oktaviani, SDN 149/X Tanjab Timur

Email: nityaoktaviani@gmail.com

\section{PENDAHULUAN}

Belajar adalah kegiatan yang dilakukan seseorang sebagai usaha untuk memperoleh ilmu untuk mendapatkan suatu kecakapan [1]. Belajar berarti berusaha memperoleh kepandaian atau ilmu. Belajar adalah kegiatan yang dilakukan secara sadar oleh seseorang melalui pembiasaan dan pengalaman untuk memperoleh tujuan berupa perubahan perilaku pada aspek-aspek pengetahuan, sikap dan keterampilan [2]. Melalui kegiatan pembelajaran seseorang mampu mencapai suatu perubahan yang baru secara keseluruhan baik dari segi sifat maupun tingkah laku. Pembelajaran adalah unsur yang saling berkaitan yang bertujuan untuk membantu proses belajar siswa, yang berisi serangkaian unsur-unsur, yaitu: Tujuan pembelajaran, materi pembelajaran, metode pembelajaran, dan evaluasi pembelajaran [3]. Pembelajaran adalah konsep dari kegiatan belajar dan mengajar yang pelaksanaannya harus direncanakan, serta diarahkan untuk mencapai tujuan, kompetensi dan indikator sebagai hasil belajar yang telah dilaksanakan. Salah satu pembelajaran di sekolah dasar adalah matematika.

Matematika merupakan ide-ide yang bersifat abstrak serta berisi simbol, maka sebelum memanipulasi simbol dalam matematika, yang harus dipahami terlebih dahulu adalah konsep-konsep matematikanya [4]. Matematika berperan dalam pendidikan serta mata pelajaran lain. Pembelajaran matematika bermanfaat untuk perkembangan berfikir siswa, melatih keterampilan berhitung siswa, dan menumbuhkan sikap kritis, kreatif, logis, cermat, dan disiplin siswa. Melalui pembelajaran matematika siswa dapat memiliki kemampuan pemecahan masalah matematis, kemampuan berkomunikasi dan kemampuan penalaran [5]. Pembelajaran matematika hendaknya bermakna, yaitu pembelajaran yang mengutamakan 
pengertian atau pemahaman konsep dan penerapannya dalam kehidupan [6]. Ada bebrapa materi pada pembelajaran matematika sekolah dasar, salah satunya adalah geometri.

Geometri adalah studi tentang bangun datar dan bangun ruang dan hubungan-hubungannya [7]. Geometri adalah cabang matematika yang berkenaan dengan posisi yang memiliki panjang dan lebar [8]. Belajar metematika yaitu meletakkan struktur hierarki dari konsep-konsep lebih tinggi yang terbentuk sebelumnya, seseorang harus mampu menemukan semua konsep yang terdapat dalam pikirannya ketika belajar geometri [9]. Keterampilan geometri dapat ditingkatkan dengan latihan soal-soal yang diambil dari buku teks matematika atau dibuat sendiri oleg guru [7]. Objek kajian geometri sangat berhubungan dengan kehidupan sehari-hari siswa. Pembelajaran geometri sering dianggap sulit oleh siswa. Diperlukan pemahaman dan proses yang cukup lama untuk menanamkan konsep materi geometri [10]. Menurut Ref [11] melalui pengalaman belajar geometri dapat meningkatkan keterampilan pemecahan masalah, penalaran dan kemudahan dalam mempelajari berbagai topik matematika, serta berbagai ilmu pengetahuan lain.

Kemampuan pemecahan masalah merupakan suatu usaha individu dengan memanfaatkan pemahaman dan keterampilan yang telah dimiliki untuk mendapatkan jalan keluar dari masalah yang dihadapi [12]. Kemampuan pemecahan masalah menjadi bagian penitng yang tidak dapat berdiri sendiri dalam proses pembelajaran matematika [13]. Melalui pembelajarn matematika ddapat meningkatkan kemmapuan pemecahan masalah siswa. Dapat dilakukan dengan cara mengarahkan pembelajaran matematika dengan pemberian tugas kepada siswa. Siswa membiasakan diri menyelesaikan soal-soal matematika sehingga dapat meningkatkan kemampuan pemecahan masalah. Kemampuan pemecahan masalah harus dikuasai oleh siswa sejak sekolah dasar agar tujuan pembelajaran matematika dapat tercapai. Salah satu cara untuk mencapai tujuan pembelajaran dapat dilakukan dengan menerapkan model pembelajaran yang menarik dan menyenangkan bagi siswa serta disesuaikan dengan karakteristik siswa dan perkembangan berfikir siswa.

Salah satu model pembelajaran yang dapat meningkatkan keterampilan pemecahan masalah adalah penggunaan model pembelajaran IOC (Inside-Outside Cicrle). Model pembelajaran IOC (Inside-Outside Circle) adalah model pembelajaran dengan kegiatan belajar siswa dibagi menjadi kelompok besar dalam kelas yang terdiri dari kelompok lingkaran dalam dan kelompok lingkaran luar, dalam kegiatan belajar siswa saling berbagi ide serta informasi [14]. Penggunaan model pembelajaran IOC (Inside-Outside Cicrle) siswa akan terlibat aktif dalam proses pembelajaran. Sehingga siswa memiliki kesempatan untuk berbagi ide yang mereka miliki untuk memecahkan masalah dengan teman kelompoknya. Guru dapat mengarahkan peserta didik dalam mengumpulkan informasi, mengembangkan keterampilan, cara berpikir, dan menyampaikan ide melalui penggunaan model pembelajaran IOC (inside-Outside Cicrle) [15]. Sehingga melalui penggunaan model IOC (Inside-Outside Cicrle) dapat meningkatkan kemampuan pemecahan masalah siswa.

Pembelajaran geometri yang sering dianggap siswa sulit, dapat diperbaiki dengan penggunan model pembelajaran IOC (inside-Outside Cicrle). Penggunaan model pembelajaran IOC (inside-Outside Cicrle) siswa dapat: a) Siswa saling bertukar informasi dalam pembelajaran. b) Materi pelajaran digunakan adalah materi yang memerlukan kegiatan saling berbagi ide dan informasi antarsiswa, materi yang dapat disesuaikan dengan model ini adalah matematika, Ilmu Pengetahuan Sosial, bahasa dan agama. c) Bisa digunakan pada semua tingkatan kelas dan disukai oleh anak-anak [16]. Pembelajaran geometri dengan menggunakan model pembelajaran IOC (inside-Outside Cicrle), akan melibatkan siswa seningga siswa akan lebih aktif, dengan meningkatkan keaktifan siswa maka kemampuan pemecahan masalah siswa dapat ditingkatkan juga. Penelitian ini adalah penelitian tindakan kelas yang bertujuan untuk menerapkan model pembelajaran IOC (inside-Outside Cicrle) untuk meningkatkan kemampuan pemecahan masalah siswa dalam pembelajaran geometri di kelas IV Sekolah dasar.

\section{METODE PENELITIAN}

Penelitian ini merupakan penelitian tindakan kelas dengan menggunakan model alur penelitian tindakan kelas menurut Kemiss dan Mc Taggart. Penelitian ini menggunakan 2 siklus dengan alokasi waktu yang digunakan yaitu 2x35 menit. Masing-masing siklus terdiri dari kegiatan perencanaan, pelaksanaan, observasi, dan refleksi [17].

JBER. Vol. 1, No. 1, Januari 2020: 7 - 15 


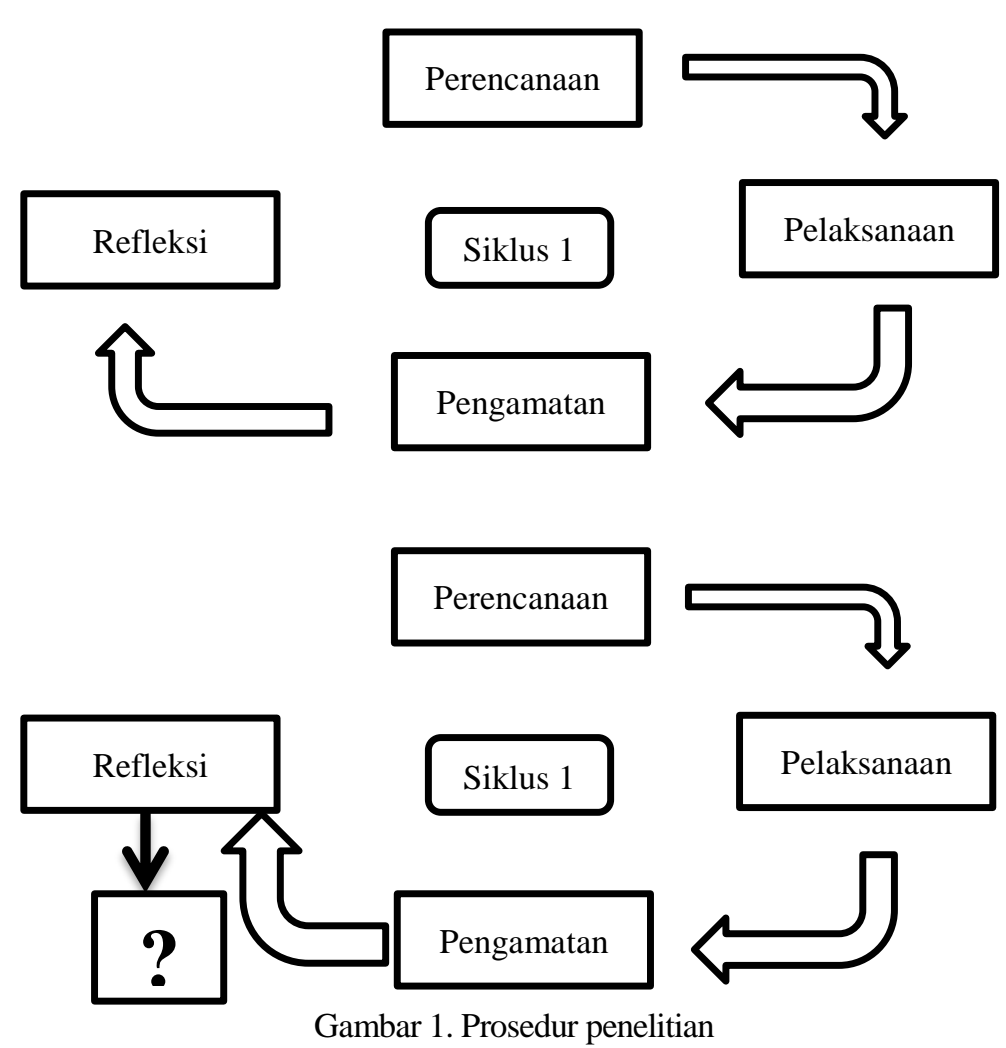

Pada penelitian ini akan dilakukan oberservasi, tes, dan dokumentasi. Observasi dilaksakan dengan cara formal untuk mengamati setiap peristiwa yang terjadi di kelas pada saat proses pembelajaran. Observasi yang dilakukan dengan cara mengamati proses pelaksanaan pembelajaran dengan model pembelajaran inside outside circle (IOC) dan observasi kemampuan pemecahan masalah siswa dalam pembelajaran geometri. Lembar observasi pemecahan masalah siswa berdasarkan tahap pemecahan masalah oleh Polya [18]. Dan kisi-kisi lembar observasi proses pembelajaran dengan model Inside-Outside Circle (IOC) menggunakan dari Ref [18]. Keberhasilan tindakan akan diketahui dengan mengetahui taraf keberhasilannya [19].

Dalam penelitian ini dilakukan tes untuk mengetahui tingkat kemampuan pemecahan masalah siswa dalam pembelajaran geometri. Tes dilakukan untuk kepentingan pengungkapan kemampuan yang berkaitan dengan kognitif [20]. Tes yang diberikan berupa tes tertulis dengan soal-soal berkaitan dengan pembelajaran geometri di kelas IV Sekolah Dasar. Tes dilaksanakan pada setiap akhir siklus dengan tujuan untuk mengetahui ketuntasan belajar siswa setelah dilakukan tindakan. Kisi-kisi instrument tes menggunakan kisikisi dari Permendikbud Nomor 24, 2016. Data hasil tes yang telah diperoleh selanjutnya dianalisis menggunakan teknik analisis deskriptif kuantitatif. Sehingga diketahui seberapa besar peningkatan kemampuan pemecahan masalah siswa. Data dari hasil penelitian dikategorikan dalam kategori penentuan nilai pada tabel Ref [21].

Kemudian dilakukan perhitungan ketuntasan klasikal dengan rumus berikut, ketuntasan belajar klasikan tercapai jika $\geq 75 \%$ siswa memperoleh skor minimal 65 yang akan dilihat pada hasil evaluasi tiaptiap siklus.

\section{HASIL DAN PEMBAHASAN}

\subsection{Hasil}

Pendidikan merupakan usaha yang dilakukan secara sadar dan terencana untuk mewujudkan suasana belajar dan proses pembelajaran agar peserta didik secara aktif mengembangkan potensi dirinya [22-24]. Pendidikan di Indonesia telah terintegrasi dengan baik dan perlu pengembangan lebih lanjut [25-26]. Keberlanjutan pendidikan semestinya berkaitan erat dengan kurikulum yang digunakan [27]. The curriculum has two aspects [28], namely as a plan that must be used as a guideline for the implementation of the teaching and learning process, and as a tool to achieve educational goals [29-30]. Sering bergantinya kurikulum di sekolah disebabkan karena sesuai atau tidak sesuai kurikulum saat diterapkan [31-33]. Kurikulum saat ini yang digunakan yaitu kurikulum 2013 revisi, sehingga peserta didik diharapkan memiliki sikap yang ilmiah dalam pembelajaran [34]; [36]. 
Penelitian ini dilaksanakan dalam satu pertemuan pra tindakan, dan beberapa siklus, masing-masing siklus dilaksanakan dalam 2x pertemuan. Dengan alokasi waktu 2x35 menit dalam satu kali pertemuan. Setelah melaksanakan observasi, peneliti memberikan tes awal kepada siswa untuk mengetahui tingkat kemampuan pemecahan masalah siswa. Didapatkan nilai tes awal seperti pada tabel 3.

Tabel 3. Rekapitulasi Nilai Tes Awal

\begin{tabular}{lcccc}
\hline No & Nilai & Kriteria & Jumlah Siswa & Persentase \\
\hline 1 & $85 \%-100 \%$ & Sangat Baik & 0 & $0 \%$ \\
2 & $75 \%-84 \%$ & Baik & 2 & $7.4 \%$ \\
3 & $65 \%-74.99 \%$ & Cukup & 6 & $22.2 \%$ \\
4 & $55 \%-64 \%$ & Kurang & 3 & $11.1 \%$ \\
5 & $<55 \%$ & Sangat Kurang & 16 & $59.3 \%$ \\
\hline \multicolumn{7}{r}{ Jumlah } & & 27 & $100 \%$ \\
\hline
\end{tabular}

Pada akhir tindakan siklus I ini dilaksanakan evaluasi belajar siswa untuk melihat tingkat pencapaian hasil belajar siswa dalam memecahkan masalah matematika. Pengukuran kemampuan pemecahan masalah ini dilakukan dengan memberikan soal-soal evaluasi secara individu kepada siswa. Hasil evaluasi siklus I dapat dilihat pada tabel berikut.

Tabel 4. Hasil evaluasi siklus 1

\begin{tabular}{|c|c|c|c|c|}
\hline No & Nilai & Kriteria & Jumlah Siswa & Persentase \\
\hline 1. & $85 \%-100 \%$ & Sangat Baik & 1 & $3.71 \%$ \\
\hline 2. & $75 \%-84.99 \%$ & Baik & 2 & $7.41 \%$ \\
\hline 3. & $65 \%-74.99 \%$ & Cukup & 16 & $59.26 \%$ \\
\hline 4. & $55 \%-64.99 \%$ & Kurang & 4 & $14.81 \%$ \\
\hline 5. & $<55 \%$ & Sangat Kurang & 4 & $14.81 \%$ \\
\hline \multicolumn{3}{|c|}{ Jumlah } & 27 & $100 \%$ \\
\hline
\end{tabular}

Dari data evaluasi tertulis siswa dalam proses pembelajaran lalu dianalisis dengan menggunakan analisis ketuntasan hasil belajar siswa secara klasikal minimal 75\% dari jumlah siswa yang memperoleh nilai 65 ke atas dengan rumus sebagai berikut. $\mathrm{P}=70.37 \%$. Hasil observasi kemampuan pemecahan masalah siswa pada pertemuan I menunjukkan pada hasil tabel berikut:

Tabel 5. Rekapitulasi Hasil Observasi Kemampuan Pemecahan Masalah Siswa

\begin{tabular}{ccccc}
\hline No & Nilai Keberhasilan & Taraf Keberhasilan & Jumlah Siswa & Persentase \\
\hline 1. & $85-100$ & Sangat Baik & 0 & $0 \%$ \\
2. & $70-84$ & Baik & 8 & $29.63 \%$ \\
3. & $55-69$ & Cukup & 5 & $18.52 \%$ \\
4. & $40-54$ & Kurang & 8 & $29.63 \%$ \\
5. & $<39$ & Sangat Kurang & 6 & $22.22 \%$ \\
\hline & & & 27 & $100 \%$ \\
\hline
\end{tabular}
berikut:

Hasil observasi kemampuan pemecahan masalah siswa pertemuan II siswa terlihat pada tabel

Tabel 6. Rekapitulasi Hasil Observasi Kemampuan Pemecahan Masalah Siswa

\begin{tabular}{ccccc}
\hline No & Nilai Keberhasilan & Taraf Keberhasilan & Jumlah Siswa & Persentase \\
\hline 1. & $85-100$ & Sangat Baik & 2 & $7.41 \%$ \\
2. & $70-84$ & Baik & 6 & $22.22 \%$ \\
3. & $55-69$ & Cukup & 12 & $44.44 \%$ \\
4. & $40-54$ & Kurang & 4 & $14.82 \%$ \\
5. & $<39$ & Sangat Kurang & 3 & $11.11 \%$ \\
\hline & & & 27 & $100 \%$ \\
\hline
\end{tabular}

Pada akhir tindakan siklus II ini dilaksanakan evaluasi belajar siswa untuk melihat tingkat pencapaian hasil belajar siswa dalam memecahkan masalah matematika. Hasil evaluasi siklus II dapat dilihat pada tabel berikut: 
Tabel 7. Rekapitulasi Nilai Tes Siklus II

\begin{tabular}{|c|c|c|c|c|}
\hline No & Nilai & Kriteria & Jumlah Siswa & Persentase \\
\hline 1. & $85 \%-100 \%$ & Sangat Baik & 16 & $59.26 \%$ \\
\hline 2. & $75 \%-84.99 \%$ & Baik & 3 & $11.11 \%$ \\
\hline 3. & $65 \%-74.99 \%$ & Cukup & 6 & $22.22 \%$ \\
\hline 4. & $55 \%-64.99 \%$ & Kurang & 2 & $7.41 \%$ \\
\hline 5. & $<55 \%$ & Sangat Kurang & 0 & 0 \\
\hline \multicolumn{3}{|c|}{ Jumlah } & 27 & $100 \%$ \\
\hline
\end{tabular}

Dari data evaluasi tertulis siswa dalam proses pembelajaran lalu dianalisis dengan menggunakan analisis ketuntasan hasil belajar siswa secara klasikal minimal $75 \%$ dari jumlah siswa yang memperoleh nilai 65 ke atas dengan rumus sebagai berikut: $\mathrm{P}=92.59 \%$. Ketuntasan klasikal sebesar 92.59\% menunjukkan bahwa evaluasi siklus II sudah kriteria ketuntasan klasikal yaitu 75\%. Hasil observasi kemampuan pemecahan masalah siswa pada siklus II di tunjukkan pada tabel 8

Tabel 8. Rekapitulasi Hasil Observasi Kemampuan Pemecahan Masalah Siswa

\begin{tabular}{|c|c|c|c|c|}
\hline No & Nilai Keberhasilan & Taraf Keberhasilan & Jumlah Siswa & Persentase \\
\hline 1. & $85-100$ & Sangat Baik & 6 & $22.22 \%$ \\
\hline 2. & $70-84$ & Baik & 8 & $29.63 \%$ \\
\hline 3. & $55-69$ & Cukup & 8 & $29.63 \%$ \\
\hline 4. & $40-54$ & Kurang & 5 & $18.52 \%$ \\
\hline 5. & $<39$ & Sangat Kurang & 0 & $0 \%$ \\
\hline \multicolumn{3}{|c|}{ Jumlah } & 27 & $100 \%$ \\
\hline
\end{tabular}

Hasil observasi kemampuan pemecahan masalah siswa pada siklus II pertemuan II di tunjukan pada tabel 9.

Tabel 9. Rekapitulasi Hasil Observasi Kemampuan Pemecahan Masalah Siswa

\begin{tabular}{ccccc}
\hline No & Nilai Keberhasilan & Taraf Keberhasilan & Jumlah Siswa & Persentase \\
\hline 1. & $85-100$ & Sangat Baik & 7 & $25.93 \%$ \\
2. & $70-84$ & Baik & 12 & $44.44 \%$ \\
3. & $55-69$ & Cukup & 6 & $22.22 \%$ \\
4. & $40-54$ & Kurang & 2 & $7.41 \%$ \\
5. & $<39$ & Sangat Kurang & 0 & 0 \\
\hline & Jumlah & & 27 & $100 \%$ \\
\hline
\end{tabular}

Dari hasil tindakan yang telah dilakukan didapatkan perbandingan hasi evaluasi dan hasil observasi kemmapuan pemecahan masalah siswa seperti pada gambar 2 .

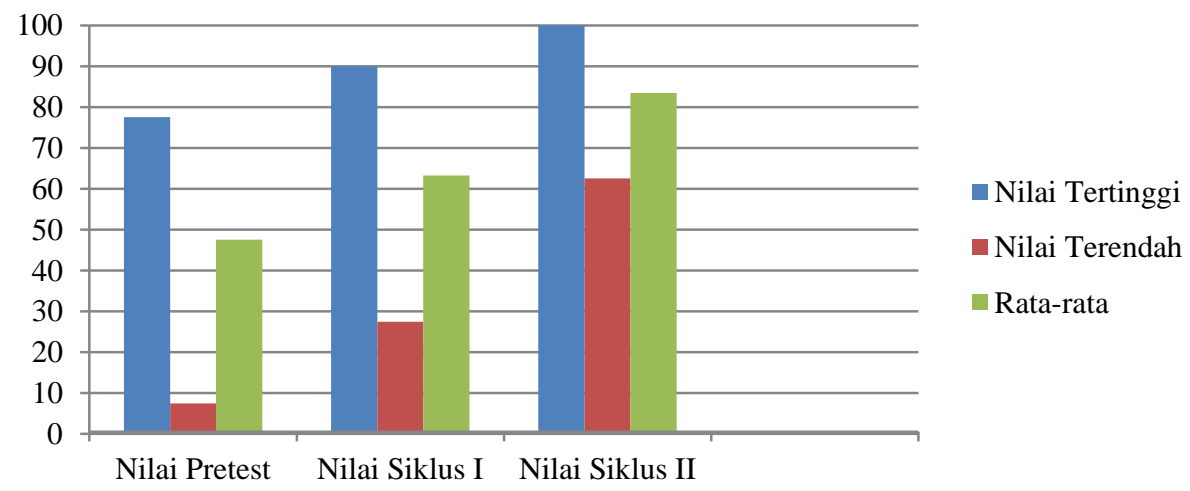

Gambar 2 Diagram Perbandingan Nilai Evaluasi Hasil Penelitian Siklus I dan Siklus II

Perbandingan Hasil observasi kemampuan pemecahan masalah siswa dalam pembelajaran geometri siklus I dan siklus II dapat dilihat pada tabel 10. 
Tabel 10. Perbandingan Hasil Observasi Kemampuan Pemecahan Masalah Siswa

\begin{tabular}{cccccc}
\hline & & \multicolumn{2}{c}{ Siklus I } & \multicolumn{2}{c}{ Siklus II } \\
\cline { 3 - 6 } No & Aspek & Pertemuan I & Pertemuan II & Pertemuan I & Pertemuan II \\
\hline 1. & Persentase Secara Klasikal & $48.15 \%$ & $74.07 \%$ & $81.48 \%$ & $92.59 \%$ \\
\hline
\end{tabular}

Persentase Kemampuan Pemecahan Masalah Siswa

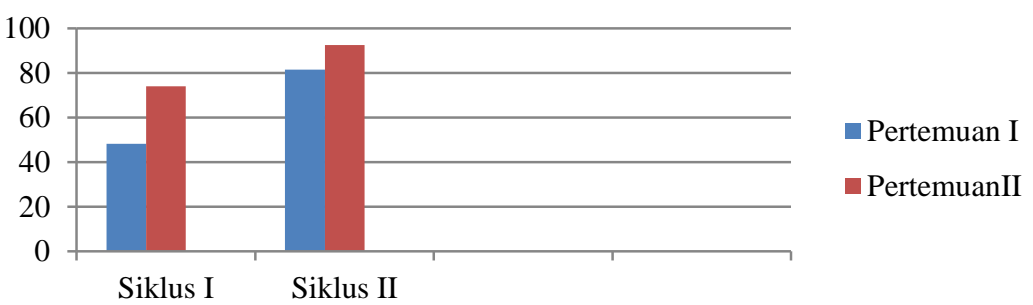

Gambar 3. Diagram Perbandingan Hasil Observasi Penelitian Setiap Pertemuan

\subsection{Pembahasan}

Penelitian ini dilaksanakan pada siswa kelas IV C Sekolah Dasar Negeri No.13/I Muara Bulian. Berdasarkan observasi awal di kelas tersebut, peneliti menemukan permasalahan kemampuan pemecahan masalah siswa dalam pembelajaran matematika masih rendah. Siswa kesulitan memecahkan soal yang diberikan, hal ini terlihat siswa kesulitan dalam menerapkan rumus atau langkah yang digunakan dalam memecahkan soal, dan siswa masih kesulitan dalam memahami masalah dari soal cerita yang diberikan.

Selanjutnya peneliti memberikan pre test mengenai tingkat kemampuan pemecahan masalah siswa. Siswa yang hadir ketika peneliti melaksanakan pre test adalah sebanyak 27 siswa, yang terdiri dari 14 siswa laki-laki dan 13 siswa perempuan. Hasil pre test menunjukkan dari 27 siswa kelas IV C hanya terdapat 8 siswa yang nilainya di atas Kriteria Ketuntasan Minimal (KKM) yang telah ditetapkan yaitu 65. Hal ini menunjukkan dari 27 siswa hanya $29.6 \%$ siswa yang mendapat nilai sesuai KKM yang telah ditentukan. Kondisi tersebut menunjukkan bahwa hasil belajar siswa belum tercapai secara maksimal dan menunjukkan bahwa kemampuan pemecahan masalah siswa dalam pembelajaran geometri masih rendah. Peneliti berkolaborasi bersama guru kelas IV C Sekolah Dasar Negeri 13/I Muara Bulian mengenai tindakan yang akan dilakukan. Peneliti dan guru sepakat untuk menerapkan model pembelajaran IOC (Inside Outside Circle). Model pembelajaran IOC (Inside Outside Circle) adalah suatu model pembelajaran yang pelaksanaan kegiatannya siswa membentuk lingkaran. Inside Outside Circle adalah kegiatan pembelajaran dengan pelaksanaan pembelajarannya siswa membentuk lingkaran terdiri dari dua lapis yaitu lingkaran dalam dan lingkaran luar sehingga membentuk pasangan kelompok [37].

Langkah pertama, siswa dikelompokkan menjadi 4-5 siswa menjadi enam kelompok. Lalu langkah kedua yaitu guru membagi tugas ke siswa dan setiap anggota memiliki tugas masing-masing. Dalam satu kelas dibagi menjadi enam kelompok, kelompok pertama mendapat tugas mengumpulkan informasi tentang sifat-sifat persegi, kelompok kedua menentukan rumus keliling dan luas persegi, kelompok tiga mendapat tugas mengumpulkan informasi tentang sifat-sifat persegi panjang, kelompok empat bertugas menentukan rumus keliling dan luas persegi panjang, kelompok lima bertugas mengumpulkan informasi tentang sifat-sifat segitiga, dan kelompok terakhir mendapat tugas menentukan rumus keliling dan luas segitiga.

Setelah selesai diskusi, selanjutnya guru meminta setiap kelompok untuk menampilkan hasil diskusi yang telah didapatkan di depan kelas. Setiap kelompok menampilkan hasil diskusi kelompok dan kelompok lain memperhatikan kelompok yang ada di depan kelas. Dalam kegiatan ini terlihat beberapa siswa yaitu MOA, MFZ, MA, RA, RE, dan ZWP yang kurang antusias ketika kelompok lain presentasi, siswa tersebut tidak fokus dalam pembelajaran dan banyak bermain-main. Namun guru terus membimbing dan menegur siswa tersebut agar memperhatikan teman yang sedang presentasi di depan.

Setelah selesai siswa menyajikan hasil diskusi, selanjutnya guru menjelaskan materi dan memberikan contoh-contoh materi atau soal. Pada kegiatan pembelajaran siklus I guru menjelaskan materi dengan menggunakan media sederhana yaitu gambar yang ada dipapan tulis. Dalam pembelajaran siklus I baik pertemuan I dan pertemuan II guru tidak menggunakan media konkret, sehingga siswa merasa cepat 
bosan dan kurang antusias dalam belajar. Selanjutnya pada pertemuan siklus II guru berinisiatif untuk menggunakan media pembelajaran agar siswa lebih semangat dalam belajar. Namun pada pertemuan I siklus II media yang digunakan masih sederhana yaitu gambar persegi, persegi panjang dan segitiga di kertas HVS. Pada pertemuan II siklus II guru menyediakan media yang lebih menarik yaitu media pembelajaran keping puzzle. Pada pertemuan kedua ini siswa terlihat lebih aktif dan antusias dalam belajar, bahkan siswa sampai berebutan untuk maju ke depan kelas untuk menjawab pertanyaan guru. Media yang digunakan ini untuk membantu siswa dalam memecahkan masalah tentang menghitung keliling dan luas persegi, persegi panjang dan segitiga dalam bentuk soal cerita.

Setelah menjelaskan materi, selanjutnya guru membagi siswa menjadi dua kelompok besar dan membentuk lingkaran kecil dan lingkaran besar sehingga saling berpasangan. Siswa mengamati cara menghitung dan mengamati contoh soal, selanjutnya siswa mengerjakan soal yang guru berikan. Dalam kegiatan ini guru berperan membimbing siswa baik secara kelompok maupun individu untuk mendorong siswa agar semangat dalam mencari dan mengumpulkan informasi. Dalam kegiatan ini dapat diamati indikator kemampuan pemecahan masalah siswa yaitu memahami masalah, menyusun rencana pemecahan masalah, dan melaksanakan rencana pemecahan masalah.

Langkah selanjutnya yaitu setiap kelompok menyampaikan hasil diskusi kelompok secara klasikal bersama kelompok. Pada siklus I dan siklus II kegiatan ini sudah terlaksana dengan baik. Semua kelompok menyampaikan hasil diskusi kelompok dengan baik. Meskipun masih ada beberapa siswa yang perlu perhatian untuk dapat fokus dalam pembelajaran yaitu MOA, MFZ, MA, RA, RE dan ZWP. Ketika kelompok menyampaikan hasil diskusi kelompok di depan kelas, siswa lain memperhatikan dengan baik dan semua aktif dalam menanggapi penyajian hasil diskusi kelompok yang maju. Siswa yang selalu aktif menanggapi dari awal kegiatan pada siklus I dan II adalah AA, AN, NK, RRZ, RJF, SF dan ZN.

Model pembelajaran Inside Outside Circle (IOC) memiliki peran dalam meningkatkan kemampuan pemecahan masalah siswa dalam pembelajaran geometri di kelas IV SD Negeri No. 13/I Muara Bulian. Kemampuan pemecahan masalah siswa meningkat dengan adanya kegiatan siswa saling berbagi informasi dan bertukar pikiran dalam memecahkan masalah yang diberikan. Siswa berbagi informasi tentang cara menghitung keliling dan luas persegi, persegi panjang, dan segitiga bersama teman sekelompok. Dalam proses pembelajaran siswa terlihat antusias dan aktif mengikuti pembelajaran dengan langkah-langkah model pembelajaran IOC.

Berdasarkan penelitian dari siklus I dan siklus II dapat disimpulkan bahwa kemampuan pemecahan masalah siswa meningkat pada pembelajaran geometri dengan menerapkan model pembelajaran IOC (Inside Outside Circle) di kelas IV C Sekolah Dasar Negeri No. 13/I Muara Bulian. Kemampuan pemecahan masalah siswa dilihat dari empat langkah dalam pemecahan masalah menurut Polya [18] yang terdiri dari "Kemampuan memahami masalah, kemampuan merencanakan penyelesaian masalah, pelaksanaan rencana pemecahan masalah, dan memeriksa kembali proses dan hasil."

Pada siklus I hasil pengamatan mengenai kemampuan pemecahan masalah siswa mengalami peningkatan pada pertemuan I yaitu sebesar $48.15 \%$ dan pertemuan II menjadi $74.07 \%$ dengan hasil evaluasi pada siklus I dengan ketuntasan klasikal sebesar 70.37\%. pada siklus I, masih terdapat kekurangan yang ditemukan pada hasil pengamatan aktivitas guru dan aktivitas siswa yaitu: waktu yang digunakan tidak cukup sehingga model pembelajaran IOC tidak dapat terlaksana sepenuhnya. Karena model pembelajaran IOC membutuhkan waktu yang cukup lama agar siswa dapat berbagi informasi mengenai kemampuan pemecahan masalah dengan pasangan kelompoknya, dalam kegiatan pembelajaran masih banyak siswa yang bermain dengan teman sekelompoknya, siswa tersebut adalah AH, MOA, MFZ, MA, RA, RE, dan ZWP, masih terdapat siswa yang kesulitan dalam mengerjakan soal latihan dan evaluasi siswa tersebut adalah AMP, MAS, MOA, MFZ, MA, RA dan ZWP, guru terlalu cepat dalam menjelaskan materi pembelajaran geometri, guru tidak menggunakan media pembelajaran sehingga antusias siswa dalam pembelajaran masih kurang.

Hasil pengamatan kemampuan pemecahan masalah siswa mengalami peningkatan pada siklus II pertemuan I yaitu sebesar $81.48 \%$ dan pertemuan II menjadi $92.59 \%$ dengan hasil evaluasi pada siklus II dengan ketuntasan klasikal sebesar $92.59 \%$ hal ini didukung oleh [37] mengatakan bahwa: penggunaan model cooperative learning tipe inside outside circle dapat meningkatkan kemampuan siswa dalam memecahkan masalah sehingga hasil belajar siswa juga meningkat. Hasil pengamatan dan hasil tes tertulis siswa telah melebihi kriteria keberhasilan, selama observasi proses pembelajaran dan evaluasi tertulis yang

Dampak Implementasi Full Day School Dalam Pelaksanaan Pembelajaran Di ... (Nitya Ruth Oktaviani) 
dilaksanakan pada siklus II menunjukkan bahwa tindakan pada siklus II sudah berjalan dengan baik. Terdapat peningkatan kemampuan pemecahan masalah siswa pada pembelajaran geometri tentang keliling dan luas persegi, persegi panjang dan segitiga. Sehingga tindakan dapat dihentikan.

Persentase keberhasilan tindakan dari hasil observasi pada saat siklus I sampai siklus II telah mengalami peningkatan pada kemampuan pemecahan masalah siswa pada pembelajaran geometri, tampak dari kemampuan siswa dalam melalkukan aktivitas belajar bersama kelompok baik secara individu atau kelompok [10]. Hasil belajar siswa dikatakan tuntas secara individual apabila mencapai nilai $\geq 65$ sebanyak 25 siswa dan hasil belajar siswa dikatakan tuntas secara klasikal apabila mencapai $\geq 75 \%$ dari jumlah siswa keseluruhan atau dalam kategori sangat baik sebanyak 92.59\%. Berdasarkan hasil observasi dan hasil tes tertulis tersebut, maka dapat disimpulkan bahwa kemampuan pemecahan masalah siswa dalam pembelajaran geometri dapat meningkat dengan menggunakan model pembelajaran IOC (Inside Outside Circle) di kelas IV C Sekolah Dasar Negeri 149/X Tanjung Jabung Timur.

\section{KESIMPULAN}

Berdasarkan penelitian tentang dampak implementasi full day school dalam pelaksanaan pembelajaran di Sekolah Dasar Negeri 149/X Tanjung Jabung Timur, maka dapat disimpulkan bahwa dampak yang ditimbulkan berupa dampak positif dan dampak negatif

\section{UCAPAN TERIMA KASIH}

Peneliti mengucapkan terima kasih kepada kepala sekolah dan guru serta siswa yang telah memberikan izin kepada para peneliti untuk melakukan penelitian ini. khususnya untuk SDN 149/X Tanjung Jabung Timur.

\section{REFERENSI}

[1] Baharuddin, and E. N. Wahyuni. "Teori Belajar dan Pembelajaran,” Ar-Ruzz Media, 2015.

[2] Aunurrahman. "Belajar dan Pembelajaran," Alfabeta, 2013.

[3] Rusman. "Pembelajaran Tematik Terpadu: Teori, Praktik dan Penilaian, Ed. 1. Cet. 1," Rajawali Pers, 2015.

[4] A. Susanto. "Teori Belajar \& Pembelajaran di Sekolah Dasar," Kencana Prenada Media Group, 2013.

[5] A. S. Malinda, Murtono, and E. Zuliana. "Problem Based Learning Berbantuan Lego Meningkatkan Pemecahan Masalah Siswa Sekolah Dasar," Online, vol. 8 no. 1, ISSN: 2087-9385, 2017.

[6] S. W. Sufri, and H. Sabil. "Pembelajaran Matematika SD," Universitas Jambi, 2010.

[7] T. Runtukahu, and S. Kandou. "Pembelajaran Matematika Dasar Bagi Anak Berkesulitan Belajar," Ar-Ruzz Media, 2016.

[8] M. Abdurrahman. "Anak Berkesulitan Belajar,” Rineka Cipta, 2012.

[9] D. Tarigan. "Pembelajaran Matematika Realistik," Departemen Pendidikan Nasional Direktorat Jenderal Pendidikan Tinggi, 2006.

[10] N. Rahmah, and Rafika. "Model Pembelajaran Kooperatif Tipe Inside-Outside Circle Dalam Pembelajaran Matematika," Journal Of Islamic Education Management, vol. 1 no. 2, pp. 1-14, 2017.

[11] Z. Sholihah, and E. A. Afriansyah. "Analisis Kesulitan Siswa Dalam Proses Pemecahan Masalah Geometri Berdasarkan Tahapan Berpikir Van Hiele," Online, vol. 6 no. 2, ISSN 2086-4280, 2017.

[12] N. Vitasari, and Trisniawati. "Peningkatan Kemampuan Pemecahan Masalah Matematis Mahasiswa PGSD Universitas Sarjanawiyata Tamansiswa Melalui Problem Posing," Online, vol. 1 no. 2, ISSN 2579-5112, 2017.

[13] G. Roebyanto, and S. Harmini. "Pemecahan Masalah Matematika," PT Remaja Rosdakarya, 2017.

[14] Y. S. Ningsih, and S. Andriani. "Penerapan Model Pembelajaran Inside Outside Circle Terhadap Kemampuan Pemahaman Konsep Siswa," MES (Journal of Mathematics Education and Science), vol. 2 no. 2, pp. 88-94, 2017.

[15] A. Suprijino. "Cooperative Learning," Pustaka Pelajar, 2016.

[16] M. Fathurrohman. "Model-model pembelajaran inovatif alternatif desain pembelajaran yang menyenangkan," Arruzz Media, 2015.

[17] S. Arikunto. "Prosedur Penelitian, Suatu Pendekatan dan Praktik," PT Rineka Cipta, 2013.

[18] A. Shoimin. "68 Model Pembelajaran Inovatif dalam Kurikulum 2013," Ar-ruzz Media, 2014.

[19] Aries, and Haryono. "Penelitian Tindakan Kelas Teori dan Aplikasinya," Aditya Media Publishing, 2012.

[20] B. Susetyo. "Prosedur Penyusunan \& Analisis Tes," PT Refika Aditama, 2015.

[21] K. Komalasari. "Pembelajaran Kontekstual: Konsep dan Aplikasi,” Refika Aditama, 2010.

[22] Asrial, Syahrial, D. A. Kurniawan, F. Chan, R. Septianingsih, and R. Perdana. "Multimedia Innovation 4.0 in Education: E-Modul Ethnoconstructivism," Universal Journal of Educational Research, vol. 7 no. 10, pp. 20982107, 2019. 
[23] Maison, Astalini, Darmaji, D. A. Kurniawan, R. Perdana, and L. Anggraini. "The Phenomenon of Physicology Senior High School Education: Relationship of Students' Attitudes Toward Physic, Learning Style, Motivation," Universal Journal of Educational Research, vol. 7 no. 10, pp. 2199-2207, 2019.

[24] A. Asrial, S. Syahrial, D. A. Kurniawan, R. Perdana, and P. Nugroho. "Supporting Technology 4.0: Ethnocontructivist Multimedia for Elementary Schools," International Journal of Online and Biomedical Engineering (iJOE), vol. 15 no. 14, pp. 54-66, 2019.

[25] A. Astalini, et al. "Description of Relationship Between Students Interest and Attitudes in Physics Subject in Indonesia," Journal of Educational Science and Technology (EST), vol. 5 no. 3, 2019.

[26] Asrial, Syahrial, D. A. Kurniawan, Maryono, P. Nugroho, and R. Perdana. "Etno-social Knowledge: How Does Knowledge of Basic School Teachers in Indonesia?," Journal of Education and Learning (EduLearn), vol. 13 no. 4, pp. 583-588, 2019.

[27] Astalini, D. A. Kurniawan, Darmaji, L. R. Sholihah, and R. Perdana. "Characteristics of Students' Attitude to Physics in Muaro Jambi High School," Humanities \& Social Sciences Reviews (HSSR), vol. 7 no. 2, pp. 91-99, 2019.

[28] Astalini, Darmaji, D. A. Kurniawan, and A. Destianti. "The Relationship Between Learning Independence and Attitude Toward Science for Junior High School Students," Jurnal Pendidikan Progresif, vol. 9 no. 2, pp.123-131, 2019.

[29] Darmaji, et al. "E-Module Based Problem Solving in Basic Physics Practicum for Science Process Skills," International Journal of Online and Biomedical Engineering (iJOE), vol. 15 no. 15, pp. 4-17, 2019.

[30] D. Darmaji, A. Astalini, D. A. Kurniawan, and R. Perdana. "A Study Relationship Attitude Toward Physics, Motivation, and Character Discipline Students Senior High School, in Indonesia," International Journal of Learning and Teaching, vol. 11 no. 3, pp. 99-109, 2019.

[31] D. Darmaji, D. A. Kurniawan, A. Astalini, and N. R. Nasih. "Persepsi Mahasiswa pada Penuntun Praktikum Fisika Dasar II Berbasis Mobile Learning," Jurnal Pendidikan: Teori, Penelitian, dan Pengembangan, vol. 4 no. 4, pp.516-523, 2019.

[32] W. Kurniawan, et al. "Multimedia Physics Practicum Reflective Material Based on Problem Solving for Science Process Skills," International Journal of Evaluation and Research in Education (IJERE), vol. 8 no. 4, pp. 590-595, 2019.

[33] Astalini, et al. "Motivation and Attitude of Students on Physics Subject in The Middle School in Indonesia," International Education Studies (IES) Journal, vol. 12 no. 9, pp. 15-26, 2019.

[34] A. Asrial, S. Syahrial, D. A. Kurniawan, and N. Amalina. "Analisis Hubungan Kompetensi Bahasa Indonesia Terhadap Kompetensi Pedagogik Mahasiswa Pendidikan Guru Sekolah Dasar," Premier Educandum: Jurnal Pendidikan Dasar dan Pembelajaran, vol 9 no. 1, pp. 1-8, 2019.

[35] Astalini, D. Darmaji, W. Kurniawan, K. Anwar, and D. A. Kurniawan. "Effectivenes of Using E-Module and EAssessment," International Journal of Interactive Mobile Technologies (iJIM), vol. 13 no. 9, pp. 21-39, 2019.

[36] Asrial, Syahrial, D. A. Kurniawan, M. Subandiyo, and N. Amalina. "Exploring Obstacles in Language Learning Among Prospective Primary School Teacher," International Journal of Evaluation and Research in Education (IJERE), vol. 8 no. 2, pp. 249-254, 2019.

[37] Y. D. Haryanti. "Peningkatan Hasil Belajar Dengan Menggunakan Model Cooperative Learning Tipe Inside Outside Circle," Online, 2(2), ISSN 2442-7470, 2016. 